\title{
Impact of Natural Disasters on Construction Projects: Strategies to Prevent Cost and Schedule Overruns in Reconstruction Projects
}

\author{
Apurva Pamidimukkala ${ }^{1}$, Sharareh Kermanshachi ${ }^{2}$ and Sanjgna Karthick ${ }^{3}$
}

1 Department of Civil Engineering, University of Texas at Arlington, Arlington, USA, apurva.pamidmukkala@mavs.uta.edu

2 Department of Civil Engineering, University of Texas at Arlington,Arlington, USA, sharareh.kermanshachi@uta.edu

3 Department of Civil Engineering, University of Texas at Arlington, Arlington, USA, sanjgna.karthick@mavs.uta.edu

\begin{abstract}
The number of natural catastrophic events has increased remarkably in recent decades, and the resulting challenges of construction projects have increased even more. It is imperative to recognize these challenges and employ suitable strategies to mitigate them to avoid project failures, which is the basis of this study. To become more knowledgeable about this subject, more than 100 scholarly articles, including peerreviewed papers and other types of publications, were reviewed and a list of eleven challenges was developed. The next step was to identify the management strategies that could be applied to overcome the challenges. The outcomes from this study concisely help decision-makers and project managers allocate their resources wisely after a disaster, implement construction activities more efficiently, and achieve higher rates of productivity while reducing the consequences of disruptive events.
\end{abstract}

(c) 2020 The Authors. Published by Budapest University of Technology and Economics \& Diamond Congress Ltd Peer-review under responsibility of the Scientific Committee of the Creative Construction Conference 2020.

Keywords: natural disasters, construction, strategy, overrun, cost and schedule

\section{Introduction}

The unexpected and destructive power of disasters diminish the social stratification and cause physical damage and psychological trauma to society and harm to the environment $[1,2,3]$. The number and severity of natural disasters has increased significantly in recent years [4]. There were only about 100 natural disasters reported annually worldwide during the 1980s, and that number has risen to over 300 since 2000 [5]. Disasters have impacted both developed and developing countries, and the United States is one of the top five countries most frequently impacted $[5,6]$. Both direct and indirect impacts of natural disasters are devastating to business activities and their community [7], as they affect many parties, such as company management, investors, suppliers, etc. [8]. The construction industry is in the maelstrom of the aftermath of the disasters, as they deal with damage to buildings and infrastructures that must be repaired immediately $[9,10,11]$. Disaster recovery made without knowledge of effective strategies results in an increase of losses $[6,12,13,14,15]$, while studying natural catastrophes facilitates better decision-making regarding the timing and planning for reconstruction materials for future disasters [16, 17].

This study aims to investigate and analyze the impacts of natural disasters on construction projects and to develop a list of resultant challenges and management strategies to address them. These research results 
will help project managers identify, prevent, and manage the challenges caused by natural disasters in construction projects and help them allocate their resources effectively.

\section{Methodology}

This research methodology includes four main steps. A thorough literature search was conducted in the first step, and more than 100 scholarly articles were reviewed to meet the objectives of this study. In the next step, the existing database was scrutinized, and data was collected. In the third

step, potential challenges were identified from the finalized database, and in the fourth step, the management strategies were identified from the literature. Finally, the conclusions were presented. Figure 1 shows the adopted methodology of this study.

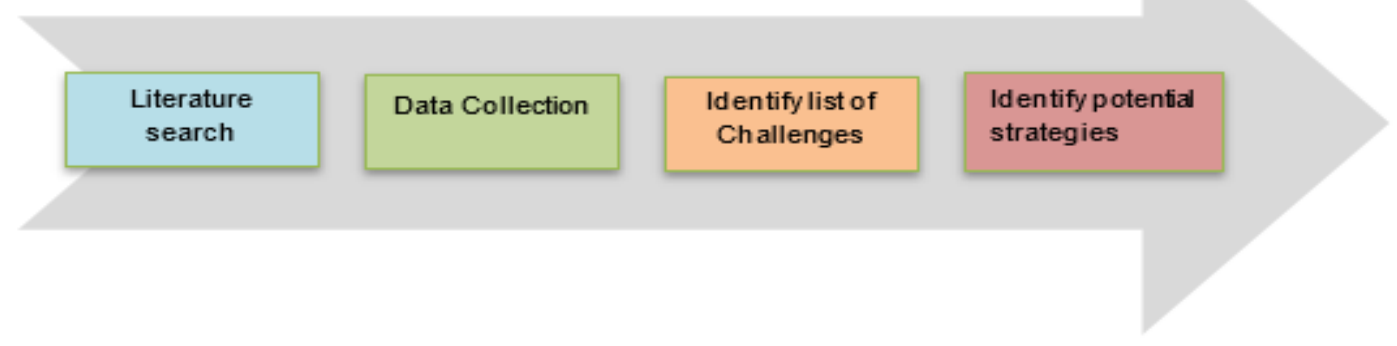

Figure 1. Research methodology

\section{Data collection}

As presented in Figure1, scholarly articles related to challenges in construction after a disaster were collected by entering various keywords in search engines like Scopus, Google scholar, Science Direct, etc. After reviewing the journal articles, essential information like the name and publication year of the articles were documented. Table 1 shows details of the reviewed journals and articles published in this area. It can be noted that the Natural Hazards journal ranked first with 9 papers, which accounted for $11 \%$ of all the papers.

Table 1. Frequency of studied journals

\begin{tabular}{lll}
\hline Journal Title & Frequency & Percentage \\
\hline Natural Hazards review & 9 & $11 \%$ \\
Journal of Computing in Civil & 7 & $9 \%$ \\
Engineering & & \\
Construction Research Congress & 5 & $7 \%$ \\
$\begin{array}{l}\text { International Journal of Disaster Risk } \\
\text { Reduction }\end{array}$ & 5 & $7 \%$ \\
Journal of Structural Engineering & 4 & $5 \%$ \\
Journal of Construction Engineering & 3 & $4 \%$ \\
and Management & & \\
Social and Behavioral Sciences & 3 & $4 \%$ \\
Sustainable Transportation Systems & 3 & $4 \%$ \\
Nature & 3 & $4 \%$ \\
Procedia Engineering & 2 & $2 \%$ \\
Disaster Prevention and Management & 2 & $2 \%$ \\
Applied Economics & 2 & $2 \%$ \\
Building Research and Information & 2 & $2 \%$ \\
Earthquake Engineering and & 2 & $2 \%$ \\
Engineering Vibration & & \\
Journal of Aerospace Engineering & 2 & $2 \%$ \\
Others & 27 & $33 \%$ \\
\hline Total & 81 & $100 \%$ \\
\hline
\end{tabular}


Although the effects of natural disasters have been experienced worldwide for many years, researchers have only recently begun to focus on the subject. The trends in the number of journal articles published over the years is depicted in the Figure 2.

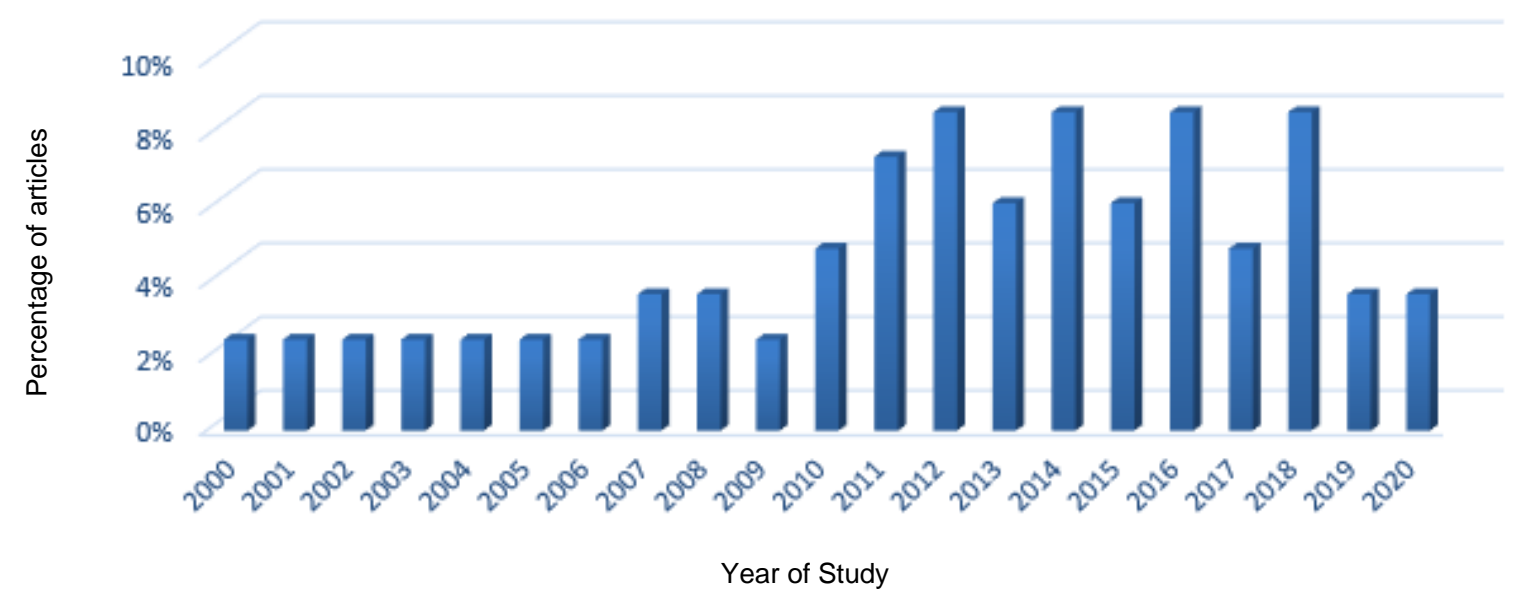

Figure 2. Distribution of articles based on year of publication

\section{Identification of challenges for construction projects created by natural disasters}

The 11 challenges observed through a thorough review of the literature are depicted in Table 2 and are discussed below.

Table 2. List of the identified challenges

\begin{tabular}{lll}
\hline$\#$ & Challenges & Source \\
\hline C1 & Increase in overhead cost and profit margins & {$[17]$} \\
C2 & Disruption of transportation network (logistics) & {$[18]$} \\
C3 & Psychological and environmental factors & {$[19]$} \\
C4 & Damages to machinery & {$[20]$} \\
C5 & Inflation of construction labor charges & {$[21]$} \\
C6 & Increase in demand for labor and equipment & {$[21,22,23]$} \\
C7 & Loss of lives and impact on neighboring communities & {$[24]$} \\
C8 & Damages to materials in construction site & {$[25]$} \\
C9 & Stability of structural components & {$[26]$} \\
C10 & Project schedule & {$[27]$} \\
C11 & Interdependent utilities & {$[28]$} \\
\hline
\end{tabular}

\subsection{Increase in overhead costs and profit margins}

Damage to the land and equipment, and loss of revenue were identified as sources of financial stress after a natural disaster. Damages to manufacturing equipment and machinery may be severe and disrupt production [20], and the loss of equipment and supplies can cause temporary cessation of construction projects, delaying the repair or restoration of structures [29]. In 2010, the aftershock of the Canterbury earthquake hit the South Island of New Zealand and impacted a large number of infrastructures, including natural heritage sites. This disaster resulted in damage to structures that led to reconstruction costs of approximately $\$ 5$ billion [30]. The cost of labor tends to inflate in the construction industry after a disaster and is considered one of the factors for cost overruns in projects [31]. Large amounts of debris are accumulated at the site and must be hauled off and dumped, and the hazardous materials need to be discarded safely [32]. All the above mentioned tasks require additional labor and equipment that incur 
additional cost and time [22,33]. For instance, the material cost of strand board increased up to $30 \%$ and tarpaulin sheets increased up to $2000 \%$ after the Sydney hailstorm [17]. Contractors often increase the overhead and profit margins and may change the bidding values in the aftermath of disasters. They also tend to increase the cost of repairs, thereby increasing the overall project cost [17].

\subsection{Logistics}

Disruptions after disasters to public and utility services such as electricity, water supply and sewage, fuel, transportations, and telecommunications can be responsible for slowing down construction [18]. Lack of facilities and public infrastructures is also an expected effect that requires projects to look at an alternative for emergency logistic support [20]. Any failure in the civil engineering services results in a disruption in delivering emergency services such as rescue operations [34]; hence, it is vital that agencies related to emergency services stay aware of the vulnerability of critical infrastructure systems [35].

\subsection{Labor}

The demand for skilled labor and construction materials drastically increases after a natural disaster and usually results in massive price escalations [21]. Shortages of resources, together with the increase in the cost of materials, slow down the post-disaster construction process [36]. The increase in repair costs following large-scale natural disasters is measured as a percentage increase in construction costs and affects the supply of construction materials and labor [37]. Sudden and temporary escalation in the cost of construction materials, labor, and services due to the increased demand following natural disasters is called "demand surge" (Subcommittee on Ratemaking of the Casualty Committee 2000). Another impact of disasters on construction sites is the increased demand for skilled laborers [23]. In New Zealand, after the 2010 and 2011 Christchurch earthquakes, there was a high demand for skilled labor. The research reports that the complexity of structures increases as disaster resiliency must be increased, and the incorporation of revised building codes, the need for innovative construction, financial constraints etc., increase the requirements for skilled labor [23]. The demand for labor begins or escalates based on the impact of the disaster. The construction industry in general and the project managers specifically should take the workforce capacity into account in the planning phase by allocating a separate cost for it and considering the risks of labor shortages [23]. The questionnaire survey conducted by the research team at Christchurch revealed that 65 percent of the poaching of laborers from other construction companies began to increase after the Queensland earthquake. Experts believe that both time and money are wasted in the pursuit of skilled workers to deliver projects with the desired quality [23].

\subsection{Psychological environmental factors}

The frequency of disaster events across the globe has led to an increase in psychological environmental risks [2]. Psychological environmental factors refer to the culture, general practices, and climate of the workplace. Natural disasters create distress among construction firms' management teams and workers, which takes the form of job insecurity, uncertainty about work contracts, and discriminatory practices affecting salaries and career development. Natural disasters also influence organizational factors [19].

\subsection{Loss of lives and impact on neighboring communities}

Unsecured materials at construction sites are vulnerable to being converted into debris, thereby causing injuries to people at the site when it gets tossed about at a high velocity [38]. When the construction site is not secure, and if it is subjected to intense wind forces, the impacts resulting from it could create a series of further damages that disturb neighboring communities. Construction sites are exposed to different types of natural disasters, including fire. During the event of fire disasters, one of the factors to be considered on a construction site is the safety of the construction crew/employers at the site. This factor must be given higher consideration when it comes to high rise building projects, as the workers have to be evacuated from each floor, which consumes a lot of time [24].

\subsection{Damages to materials and machinery at construction sites}

Depending on the magnitude of the wind force, materials at construction sites, such as steel props, plywood, and other heavy objects, can be thrown about at a very high speed. Residential projects that 
employ light wooden frame construction are significantly impacted by disasters like hurricanes [25]. From several surveys conducted by the author to study the impacts of Hurricane Sandy, it became evident that the residential structures that were built using light wooden frames at Ortley Beach, located on the narrow peninsula between Barnegat Bay and the Atlantic Ocean, were hit the hardest by the storm surge. In coastal areas, frontal dunes act as shelter to other structures by absorbing the impact. The coastal dunes on Ortley Beach were damaged, and as a result the structures were exposed to higher loads from waves, which led to failure. In addition to damages resulting from storm surges, inadequately designed structures generate water-borne debris when they become fragments, resulting in increased havoc as it carries high impact from waves as well as the debris [25]. Huge amounts of raw materials are wasted at construction sites due to disasters. Generally, there is a high demand for procuring construction materials at a regional level following a serious disaster [32]. After the Wellington disaster in New Zealand, the demand for aggregates increased at the regional level, as the local markets were not able to produce adequate quantites because of the disaster's impact on the quarries [39]. Demands for cement also increased, and as the manufacturing unit was able to work only for a limited time and produce less, materials had to be imported from international markets which further increased costs [39].

\subsection{Stability of structural components}

Structures under construction do not have any fire protection systems or earthquake-resistant elements, which makes them highly prone to destruction during disastrous events [38]. Coastal structures and projects face inundation from storm surges, and the site can experience hydrostatic uplift as a result of the buoyant force that develops from air pockets and can turn into debris in the water or obstacles holding water. This results in weakening the structural components. Numerous structures and structures under construction were destroyed or weakened by storm surges during Hurricane Katrina [26]. The pavements had lower strength in the strength penetration tests conducted by the Louisiana Transportation Research Centre after the impact of the hurricane [40].

\subsection{Project schedule overruns}

One of the common issues that construction companies face following a disaster is schedule overruns [3, 27, 41]. In the Aegean Highway Project that involved three identical tunnels of $22 \mathrm{~km}$ length, one of the tunnels adjacent to an existing national road faced breakdown as huge rocks fell over the road, causing the death of the project manager on the site. The investigators were unable to determine whether the disaster occurred because of the natural phenomena or technical issues, but there was no emergency plan in place, which resulted in a delay in the completion of the project $[16,42]$. Various unexpected situations can occur that impact the completion of construction and reconstruction projects and might increase the project costs $[6,43]$. These unexpected situations can arise from factors such as a weakening of the economy; political wars; socioeconomic conditions; technical errors due to lack of skilled workers; improper site conditions; and natural disasters such as earthquakes, hurricanes, and floods $[13,43]$.

\subsection{Interdependent utilities}

Huge catastrophic events like Hurricane Katrina affect construction sites by damaging equipment, disrupting utility lines such as those for electricity and water, and creating debris. In 2012, Hurricane Sandy resulted in $\$ 185$ million damage to World Trade Centre construction site, and disrupted interdependent utilities. Underground infrastructures such as water distribution systems and waste-water collection networks are exposed to higher pressures and external loads during such events and require high levels of strength to withstand such intense pressures. Hurricane Rita that occurred in 2005 in Louisiana damaged the wastewater treatment plants to the extent that it took nearly two weeks to restore their function [28]. These types of underground structures and components will have a shorter life span than what was initially predicted for them because of corrosion caused by the accumulation of debris and water seepage during disastrous events like floods [44].

\section{Identification of management strategies}

Potential management strategies were collected from the literature to lessen the impact of challenges. Table 3 shows the list of identified strategies, some of which are discussed below. 
Since disasters such as hurricanes and typhoons create serious damage to materials and machinery on construction sites, developments are emerging that will enhance the level of preparedness and reduce the amount of losses to the public $[45,46,47,48]$. The literature highlights the importance of new imaging for simulation frameworks that aids in discovering the risks that are caused by wind-induced disasters [38]. The imaging depicts a clear picture of the extent to which the construction site will face damages by predicting the force at which the objects in the construction site could travel. This enables laborers to be proactive in preparing construction sites for possible disasters and at the same time reduce the number of laborers required to carry out the operations as a result, reducing the cost for inspecting the site [38]. Recently, the construction industry has begun to use radio frequency Identification technology (RFID), an automated tracking device that tracks materials at the site and has been shown to save $3.1 \%$ of the construction cost [49] in recovering construction operations.

Another recommended strategy is adopting the Geographical Information System, which helps in debris removal. The removal of debris following a disaster is a time-consuming, expensive, and intensive process that requires heavy equipment that sometime encounters spatial constraints [41]. The schedule and cost of a project overrun can be significantly reduced if proper preparedness tools are considered during the planning phase. A balanced scorecard method can be adopted [27], and plans can be put in place for procuring materials and modifying the construction in the event of disaster [39]. A recovery model was proposed for dealing effectively with unanticipated situations by using existing approaches and PMBOK's knowledge to recover construction projects after a disaster [42]. The model developed, by the author, focuses on identifying major hazards and planning effective methods to deal with such unanticipated situations in the pre-disaster phase, and planning activities that will help return the project back to its normal functioning state with as little damage as possible in the post-disaster phase.

Table 3. Strategies for the identified challenges

\begin{tabular}{|c|c|c|}
\hline \# & Challenges & Management Strategies \\
\hline 1 & C3 & Enhancing teamwork by team performance training \\
\hline 2 & C9 & $\begin{array}{l}\text { Adopting AD-CIRC model to derive storm surge for identifying the damages } \\
\text { caused to structural components }\end{array}$ \\
\hline 3 & C6 & Accessing Geographical Information System \\
\hline 4 & C5 & Using a simulation dynamics (SD) model to make decisions about the labor force \\
\hline 5 & C1 & Incorporating RFID to track materials in construction sites \\
\hline 6 & C1 & $\begin{array}{l}\text { Using multi linear regression models for predicting an approximate increase in } \\
\text { cost }\end{array}$ \\
\hline 7 & C4, C8 & $\begin{array}{l}\text { Using imaging to simulate a framework to reduce the damage caused to } \\
\text { materials, machinery }\end{array}$ \\
\hline 8 & $\mathrm{C} 7$ & $\begin{array}{l}\text { Incorporating simulation software to create emergency plans for evacuation of } \\
\text { workers }\end{array}$ \\
\hline 9 & $\mathrm{C} 2, \mathrm{C} 11$ & $\begin{array}{l}\text { Employing the Bayesian network theory and system dynamics simulation to } \\
\text { assess the criticality of the infrastructure }\end{array}$ \\
\hline 10 & C10 & Adopting the balance score method to reduce overruns \\
\hline
\end{tabular}

Although OSHA provides safety regulations for means of egress, the practical implementation can be attributed to the emergency plans adopted by the contractor. Emergency plans include real life drills that use fake alarm systems. These drills hinder the construction activity and schedule, causing minor delays in project activity and increasing the overhead cost. Irrespective of the number of practice drills, the behavior of the workers might vary during the actual evacuation environment. In order to overcome the abovementioned challenges, the author in [24] proposes a simulation framework that assists contractors in assessing the evacuation of the crew throughout the project's duration.

Psychological and environmental factors affecting the working conditions of the crew can be improved by conducting team performance training and encouraging teamwork, thereby increasing the workers' behavioral attributes, collaboration within the construction crew, and production [50]. The author in [51] highlighted the importance of the AD-CIRC model, which helps predict storm surges and the damages that will be caused to structural components. This model provides an opportunity to design buildings that have the structural stability to withstand such heavy forces. In the aftermath of disasters, critical infrastructures 
must be identified, and their restoration must be given priority [17]. To assess the criticality of critical infrastructures, the author in [35] introduced a decision support system, using the Bayesian network theory and system dynamics simulation system. A multilinear regression model developed by the author in [52] can be used for predicting approximate increases in cost, which helps in allocating sufficient funds in the planning phase. The simulation dynamics (SD) developed by author in [53] helps managers maker sounder decisions pertaining to whether to hire more laborers or operate with the currently available workforce.

\section{Conclusion}

This study conducted a thorough literature review on the challenges and potential management strategies used in construction projects after a disaster and revealed 11 challenges that can significantly affect the progress of a project after a disaster. Increases in costs and overhead margins is one of the most important challenges noted in the literature; other important challenges are an increase in demand for labor and equipment and disruption of transportation networks. This review also identified 10 potential strategies that are effective in controlling the challenges. Among those strategies, accessing geographical Information systems, and using multilinear regression models and the Bayesian network theory were found to be the most important. It is expected that the outcomes of this study will help project managers and policymakers better understand the challenges following a natural disaster and will enable them to prioritize their resources in a productive manner.

\section{References}

[1] Rouhanizadeh, B., \& Kermanshachi, S. "Investigating the Relationships of Socioeconomic Factors Delaying Post-Disaster Reconstruction". In Proceedings of ASCE International Conference on Computing in Civil Engineering, pp. 17-19. 2019. https://doi.org/10.1061/9780784482445.005

[2] Rouhanizadeh, B.; Kermanshachi, S. "Gender-based evaluation of physical, social, and economic challenges in natural disasters management". ASCE Construction Research Congress (CRC), 2019

[3] Safapour, E.; Kermanshachi, S. "Identification and categorization of factors affecting duration of post-disaster reconstruction of interdependent transportation systems". ASCE Construction Research Congress (CRC), 2019.

[4] Kermanshachi, S.; Bergstrand, K.; Rouhanizadeh, B. "Identifying, weighting and causality modeling of social and economic barriers to rapid infrastructure recovery from natural disasters: A study of hurricanes Harvey, Irma and Maria". Technical report, 2019.

[5] Guha-Sapir, D., Hoyois, P., and Below, R. "Annual Disaster Statistical Review 2014, The numbers and trends". Centre for Research on the Epidemiology of Disasters, 2015

[6] Rouhanizadeh, B.; Kermanshachi, S.; Dhamangaonkar, V. "Identification and categorization of policy and legal barriers to long-term timely post-disaster reconstruction". Journal of Legal Affairs and Dispute Resolution in Engineering and Construction, Volume 11 issue 3, 2019. https://doi.org/10.1061/(asce)la.1943-4170.0000307

[7] Pamidimukkala, A., Kermanshachi, S., Sofapour, E."Challenges in post disaster housing reconstruction: Analysis of urban Vs rural communities". Creative Construction Conference, 2020.

[8] Low, S. P., Liu, J., \& Sio, S. "Business continuity management in large construction companies in Singapore". Disaster Prevention and Management, 19(2), 219-232. 2010. https://doi.org/10.1108/09653561011038011

[9] Rouhanizadeh, B.; Kermanshachi, S.; Dhamangaonkar, V. "Reconstruction of critical and interdependent infrastructures due to catastrophic natural disasters: lessons learned". ASCE Construction Research Congress, 2019.

[10] Nipa T, J., Kermanshachi, S., Ramaji I, J. Comparative analysis of strengths and limitations of infrastructure resilience measurement methods. $7^{\text {th }}$ CSCE International Construction Speciality Conference (ICSC), 2019

[11] Nipa T, J., Kermanshachi, S. Identification of the Resilience Dimensions and Determination of their Relationships in Critical Transportation Infrastructures. ASCE Construction Research Congress (CRC), 2019

[12] Boschman, J. S., van der Molen, H. F., Sluiter, J. K., \& Frings-Dresen, M. H. W. "Psychosocial work environment and mental health among construction workers". Applied Ergonomics, 44(5), 748-755. 2013. https://doi.org/10.1016/j.apergo.2013.01.004

[13] Rouhanizadeh, B.; Kermanshachi, S. "A systematic approach to analysis and prioritization of the socioeconomic policy and legal barriers to rapid post disaster reconstruction". $7^{\text {th }}$ CSCE International Construction Specialty Conference, 2019.

[14] Pielke Jr, R. A. "Meteorology: Are there trends in hurricane destruction?". Nature, 438(7071), E11. 2005. https://doi.org/10.1038/nature04426

[15] Pielke Jr, R. A., Gratz, J., Landsea, C. W., Collins, D., Saunders, M. A., \& Musulin, R. "Normalized hurricane damage in the United States: 1900-2005". Natural Hazards Review, 9(1), 29-42. 2008. https://doi.org/10.1061/(ASCE)1527-6988(2008)9:1(29)

[16] Rouhanizadeh, B.; Kermanshachi, S.; Nipa, T. J. "Identification, categorization, and weighting of barriers to timely post-disaster recovery process". ASCE International Conference on Computing in Civil Engineering, 2019. Olsen, A. H., \& Porter, K. A. "What We Know about demand surge: Brief summary". Natural Hazards Review, 12(2), 62-71, 2011. https://doi.org/10.1061/(ASCE)NH.15276996.0000028

[17] Olsen, A. H., \& Porter, K. A. "What We Know about demand surge: Brief summary". Natural Hazards Review, 12(2), 62-71, 2011. https://doi.org/10.1061/(ASCE)NH.1527-6996.0000028

[18] Zhang, Y., Michael K. Lindell, and Carla S. Prater. "Modeling and managing the vulnerability of community businesses to environmental disasters", 2004. https://doi.org/10.1111/j.1467-7717.2008.01061.x

[19] Takim, R., Talib, I.F.A., Nawawi., A.H. "Quality of life: Psychosocial environment factors (PEF) in the event of disasters to private construction firms". Procedia - Social and Behavioral Sciences 234 (2016) 28 - 35, 2016. https://doi.org/10.1016/j.sbspro.2016.10.216

[20] Samantha, G. "The impact of natural disasters on micro, small and medium enterprises (MSMEs): A Case Study on 2016 flood event in Western Sri Lanka". Procedia Engineering 212 (2018) 744-751, 2018. https://doi.org/10.1016/j.proeng.2018.01.096 
Proceedings of the Creative Construction e-Conference (2020) 061

Available online at e-2020.creative-construction-conference.com/proceedings/

[21] Parker, M. "The impact of disasters on inflation". Economics of Disasters and Climate Change. 1-28, 2017. https://doi.org/10.1007/s41885-017-0017-y

[22] Swan, R. C. "Debris management planning for the 21st Century". Natural Hazards Review, 1(4), 222-225, 2000. https://doi.org/10.1061/(ASCE) 1527-6988(2000)1:4(222)

[23] Chang-Richards, Yan \& Wilkinson, Suzanne \& Seville, Erica \& Brunsdon, David. "Effects of a major disaster on skills shortages in the construction industry: Lessons learned from New Zealand". Engineering, Construction and Architectural Management. 24. 2-20, 2017. https://doi.org/10.1108/ECAM-03-2014-0044.

[24] Said, H., Kandil, A., \& Cai, H. "Agent-based simulation of labour emergency evacuation in high-rise building construction sites". Construction Research Congress, 2012. https://doi.org/10.1061/9780784412329.111

[25] Hatzikyriakou, A., Lin, N., Gong, J., Xian, S., Hu, X., \& Kennedy, A. "Component-based vulnerability analysis for residential structures subjected to storm surge impact from Hurricane Sandy". Natural Hazards Review, 17(1), 05015005, 2016. https://doi.org/10.1061/(ASCE)NH.1527-6996.0000205

[26] Robertson, I. N., Riggs, H. R., Yim, S. C., \& Young, Y. L. "Lessons from Hurricane Katrina storm surge on bridges and buildings". 2007. https://doi.org/10.1061/(ASCE)0733-950X(2007)133:6(463)

[27] Chavez, Michelle S. "Hurricane preparedness in a construction site: A framework to assess the construction companies' current practices". FIU Electronic Theses and Dissertations. 3047, 2016. https://doi.org/10.25148/etd.fidc001187

[28] Matthews, J. C. "Disaster resilience of critical water infrastructure systems". Journal of Structural Engineering, 2016. https://doi.org/10.1061/(ASCE)ST.1943-541X.0001341

[29] Safapour, E., Kermanshachi, S., Nipa, T.J. A Damage-based Analysis of Rework in Reconstruction of Infrastructure Projects Due to Natural Disasters. Creative Construction Conference (CCC), 2020.

[30] Potter, S. H., Becker, J. S., Johnston, D. M., \& Rossiter, K. P. "An overview of the impacts of the 2010-2011 Canterbury earthquakes". International Journal of Disaster Risk Reduction, 14(1), 2015. https://doi.org/10.1016/j.ijdrr.2015.01.014

[31] Safapour, E., Kermanshachi, S., Nipa, T.J. Analysis of Cost Performance Indicators in Reconstruction Projects: A Comparative Study of Low Vs. High Level Damages. Creative Construction Conference (CCC), 2020.

[32] Safapour, E., Kermanshachi, S. Investigation of the Challenges and Their Best Practices for Post-Disaster Reconstruction Safety: Educational Approach for Construction Hazards. Transportation Research Board 99th Annual Conference, 2019

[33] Kermanshachi, S., \& Rouhanizadeh, B. "Feasibility analysis of post disaster reconstruction alternatives using automated BIM-based construction cost estimation tool". In Proceeding of CSCE 6th International Disaster Mitigation Specialty Conference, Montreal: Canadian Society of Civil Engineering, pp. 13-16. 2018.

[34] Xie, L., \& Qu, Z. "On civil engineering disasters and their mitigation". In: Earthquake Engineering and Engineering vibration, V.17, n.1, 2018. https://doi.org/10.1007/s11803-018-0420-6

[35] Oh, E. H., Deshmukh, A., \& Hastak, M. "Vulnerability assessment of critical infrastructure, associated industries, and communities during extreme events". Construction Research Congress, 2010. https://doi.org/10.1061/41109(373)45.

[36] Chang, Y., Wilkinson, S., Seville, E., \& Potangaroa, R. "Changes in resource need for post-disaster reconstruction: a longitudinal study in China". Building Research \& Information, 40(3), 327-336, 2012. https://doi.org/10.1080/09613218.2012.684867

[37] Kuzak, D., and Larsen, T. "Use of catastrophe models in insurance rate making. Chapter 5, Catastrophe modeling: A new approach to managing risk". P. Grossi and H. Kunreuther, eds., Springer, New York, 2005. https://doi.org/10.1007/0-387-23129-3_5

[38] Ham, Y., Lee, S. J., \& Chowdhury, A. G. "Imaging-to-simulation framework for improving disaster preparedness of construction projects and neighboring communities". Computing in Civil Engineering, 2017. https://doi.org/10.1061/9780784480830.029

[39] Singh, B., \& Wilkinson, S. "Post-disaster resource availability following a Wellington earthquake: aggregates, concrete and cement". Building resilience, 2008

[40] Zhang, Z., Wu, Z., Martinez, M., \& Gaspard, K. "Pavement structures damage caused by Hurricane Katrina flooding". Journal of geotechnical and Geoenvironmental Engineering 134(5), 633-644, 2008. https://doi.org/10.1061/(ASCE)1090-0241(2008)134:5(633)

[41] Safapour, E., Kermanshachi, S., Nipa, T.J. Schedule Performance Analysis of Infrastructure Reconstruction Projects Due to Extreme Events. Creative Construction Conference (CCC), 2020.

[42] Anthopoulos, L. G., Kostavara, E., \& Pantouvakis, J.-P. "An effective disaster recovery model for construction projects". ProcediaSocial and Behavirol Sciences, volume 74, 21-30, 2013. https://doi.org/10.1016/j.sbspro.2013.03.026

[43] Rouhanizadeh, B.; Kermanshachi, S. "Comparative analysis of public's and decision-maker's perspectives on socioeconomic barriers causing delay in post-disaster recovery processes". ASCE Construction Research Congress (CRC), 2019.

[44] Chisolm, E. I., \& Matthews, J. C." Impact of hurricanes and flooding on buried infrastructure". Construction Research Congress, 2012. https://doi.org/10.1061/(ASCE)LM.1943-5630.0000182

[45] Nipa, T. J.; Kermanshachi, S.; Patel, R.; Tafazzoli, M. "Disaster preparedness education: construction curriculum requirements to increase students' preparedness in pre-and post-disaster activities". Associated Schools of Construction (ASC) International Conference, 2020.

[46] Patel, R, Kermanshachi S, Nipa, T, J. Establishment of a Framework to Measure Disaster Preparedness: Development of Strategies to Enhance Disaster Preparedness Activities. Creative Construction Conference (CCC), 2020

[47] Nipa, T. J.; Kermanshachi, S.; Patel, R. Impact of Family Income on Public's Disaster Preparedness and Adoption of DRR Courses. Creative Construction Conference (CCC), 2020

[48] Patel R, Kermanshachi S, Mostafa N. A Socioeconomic-based Analysis of Disaster Preparedness, Awareness, and Education. Creative Construction Conference (CCC), 2020

[49] Wang, H., Hubbard, B.J., \& Hubbard, S. "RFID applied to supply chain logistics in disaster recovery. In Randy R. Rapp \& William Harland (Eds.)". The Proceedings of the 10th International Conference of the International Institute for Infrastructure Resilience and Reconstruction (I3R2) 20-22 (207-211). West Lafayette, Indiana: Purdue University, 2014. https://doi.org/10.5703/1288284315373.

[50] Mitropoulos, P., \& Memarian, B. "Team processes and safety of workers: cognitive, affective, and behavioral processes of construction crews". Journal of Construction Engineering and Management Volume 38 issue 10, 2012. https://doi.org/10.1061/(ASCE)CO.1943-7862.0000527

[51] Brackins, J.T., \& Kalyanapu, A.J. "Using ADCIRC and HEC-FIA modeling to predict the storm surge impact on coastal infrastructure". World Environment and Water Resources Congress, 2016. https://doi.org/10.1061/9780784479841.023

[52] Olsen, A. H., Porter, K.A. "On the contribution of reconstruction labor wages and material prices to demand surge". SESM-11-1, 2011

[53] Kumar,S., Diaz, R., Behr, J.G.,Toba, A.L. "Modeling the effects of labor on housing reconstruction: A system perspective". International Journal of Disaster Risk reduction volume 12, 154-162, 2015. https://doi.org/10.1016/j.ijdrr.2015.01.001 